\title{
East Asian Trade before/after 1590s Occupation of Korea: Modeling Imports and Exports in Global Context
}

\author{
Dennis O. FLYNN and Marie A. LEE \\ University of the Pacific \\ Stockton, California, US \\ doflynn@pacific.edu
}

\begin{abstract}
The purpose of this essay is threefold. First, to highlight research of Seonmin KIM, whose 2006 Ph.D. dissertation elucidates complex relationships among Ming China, Choson Korea, Tokugawa Japan, and mountainous ginsengproducing "borderlands" between Korea and China; her story concludes with the remarkable rise of a borderlands power that overthrew Ming China, thereby establishing dominance that lasted into the $20^{\text {th }}$ century - the Qing Dynasty. A second purpose is to showcase application of a non-standard-model - the Hydraulic Metaphor - that elucidates economic components of Professor KIM's history via visual and intuitive mechanisms designed to be understandable for non-specialists. Last, an outline of East Asian history is placed within
\end{abstract}

* An early version of this essay was a keynote presentation at the $2^{\text {nd }}$ meeting of the Asian Association of World Historians at Ewha Womans University in Seoul, South Korea in May 2012. Encouragement and suggestions by Ji-Hyung CHO and Seohyung KIM, respectively Director and Research Professor, at Ewha's Institute of World and Global History are hereby acknowledged. Thanks to Professors Richard von GLAHN and SHIMADA Ryuto we eliminated a glaring error in an early draft, but of course errors and omissions that remain are our responsibility alone. 
context of centuries of monetary evolution that eventually yielded the late-16 ${ }^{\text {th }}$ century birth of globalization.

\section{Keywords}

Unified Theory of Prices; Hydraulic Metaphor, East Asian trade, Korean Trade, Invasion of Korea, 1590s, Ginseng, American and Japanese Silver, Chinese Silks, Borderlands, Transition from Ming to Qing Dynasty.

\section{OLD WORLD SILVER BEFORE GLOBALIZATION}

A decisive step toward a silver-based economy in China occurred through substitution of silver and silver-backed paper money in place of copper-based coins during the $13^{\text {th }}$ century C.E. ${ }^{1}$ Nonetheless, unification of trade across EurAsia under the Mongols led to $13^{\text {th }}$-century export of Chinese silver in response to powerful inventory demand for silver in Muslim states from Persia to Spain, where silver's purchasing power elevated to double its level in China. ${ }^{2}$ The straightforward logic is that demand-side forces helped raise the purchasing power of silver in West Asia and the Mediterranean, while the purchasing power of silver was simultaneously reduced in East Asia due to substitution of (silver-backed) paper money in place of silver itself within China. Simply put, it was profitable to relocate silver from low-value markets within China to high-value markets in western EurAsia and Africa.

Decisive change occurred again during the $15^{\text {th }}$ century when Chinese fiscal crises led to excessive issuance of paper money. Resulting bouts of hyperinflation destroyed China's silver-exchange standard by the 1430s, at a time of sharp decline in Chinese silver

${ }^{1}$ By the 1430s the Ming court adopted uncoined silver as the basis of its fiscal and monetary systems, thus displacing a low-value-bronze-coin monetary system. Richard von Glahn, Fountain of Fortune: Money and Monetary Policy in China, 1000-1700 (Berkeley and Los Angeles: University of California Press, 1996), 56. Von Glahn provides details of this crucial shift to a silver-based system. Von Glahn, "Monies of Account and Monetary Transition in China, Twelfth to Fourteenth Centuries," Journal of the Economic and Social History of the Orient 53, no. 3 (2010): 463-505.

${ }^{2}$ Von Glahn, Fountain of Fortune, 60. 
mine production. ${ }^{3}$ Abandonment of paper money resulted in increasing reliance upon silver by private merchants, and subsequently by local governments, despite Ming efforts to thwart relentless silver conversions empire-wide. Consequently, productionside collapse coupled with demand-side surge over time catapulted silver's market value within China to double its purchasing power in the Mediterranean world. In short, silver became significantly overvalued within Ming China in dramatic reversal of the prior undervaluation of silver in China during the Mongol period. Given newly-favorable markets for silver in China, the neighboring Chosŏn court permitted silver mining in Hamgyôn province in 1515 and Korean "silver continued to flow out of the country and even gained a reputation in China as high quality silver."

While no one seems to have argued that high silver prices in China stimulated the mid-fifteenth-century silver-mining boom in Central Europe, this conclusion seems a distinct possibility. Venetian silver exports eastward alone were double the combined mint output of England and the Low Countries. According to Munro5: "The very marked difference in bimetallic ratios certainly indicates that silver was generally always scarcer and thus relatively more valuable...in eastern Asia than it was in Europe." Ottoman invasion/conquest of important Central European mining regions eventuated in a 1503 Ottoman-Venetian treaty and the English Levant Company was founded in 1581 , both negotiated for the explicit pur-

${ }^{3}$ Ibid., 83-113.

${ }^{4}$ Seonmin Kim, "Borders and Crossings: Trade, Diplomacy and Ginseng between Qing China and Choson Korea" (PhD diss., Duke University, 2006), 213.

5 John H. Munro, "South German Silver, European textiles, and Venetian trade with the Levant and Ottoman Empire, c. 1370 to c. 1720: A Non-Mercantilist Approach to the Balance of Payments Problem," in Relazione economiche tra Europa e mondo islamico, seccoli XIII-XVIII, Atti delle "Settimana de Studi" e altri convegni, no 38 Insituto Internazionale di Storia Economica "Francesco Datini," ed. S. Cavaciocchi (Le Monnier, Florence, 2007), 925, 944. 
pose of exporting silver eastward through Ottoman commercial networks. ${ }^{6}$

Japan's only significant silver mines prior to the $16^{\text {th }}$ century were located on the island province of Tsushima, halfway between Korea and Kyushu island, which also served as vector for introduction of Chinese mining technology to Japan via Korea. Silver from Tsushima was evidently insufficient to satisfy domestic markets, however, since Japan imported silver from China from the late $11^{\text {th }}$ century into the $15^{\text {th }}$ century.

Despite its later reputation as a primary silver supplier to China, Japan was in fact not always an exporter of precious metals. In the midfifteenth century, the silver and copper coins circulating in Japan were largely from foreign countries....The major source of foreign currency was Korea....It was in the mid-fifteenth century when silver began to be smuggled from Korea to Japan. ${ }^{7}$

In sum, it should be kept in mind that silver flowed from China into Japan prior to the sixteenth century, and perhaps a portion of that 'Chinese' silver originated in Central European mines.

MERGER OF NEW WORLD AND OLD WORLD SILVER:

GLOBALIZATION'S BIRTH DURING THE POTOSí-JAPAN CYCLE OF SILVER (154OS-1640S)

\section{SINO-SPANISH AMERICAN CONNECTIONS}

The most spectacular silver mines in world history were discovered in Spanish America (Upper Peru and Mexico), including unrivaled silver deposits at Potosí (in modern-day Bolivia) in 1545. Spanish

${ }^{6}$ For silver flows through Ottoman territories from a global perspective, see Dennis O. Flynn and Arturo Giráldez, "Silver and Ottoman Monetary History in Global Perspective," Journal of European Economic History 31, no. 1 (Spring 2002): 9-43.

${ }^{7}$ Kim, "Borders and Crossings," 214. 
America was the only region to out-produce Japan. ${ }^{8}$ Attman estimated American silver production at more than 300 metric tons per year during the seventeenth century, compared with Japanese production of at least 200 metric tons per year early in the $17^{\text {th }}$ century. ${ }^{9}$ Much of world silver production - Japanese and American alike - was attracted to Chinese markets due to favorable silver prices in China; according to the same logic, relatively cheap Chinese (non-silver) exports - such as silks and ceramics - were attracted to markets worldwide that beckoned with price offers several times higher than Chinese prices for these items.

Historians a generation ago wrote as if massive imports of precious metals from the Americas were destined for end-market customers within European nation-states. As scholars began to subsequently re-conceptualize American silver in global (rather than European) perspective over the past 30+ years, however, a less-Eurocentric picture has emerged. American silver was not exported to Europe; American silver was exported to China through Europe (and through India as well during certain time periods). Silver values were ultimately determined in global markets, not in national markets.

American silver traversed myriad trade routes toward end markets that beckoned via elevated prices for the white metal, notably Chinese markets during the "Potosí-Japan Cycle of Silver" (1540s to 1640s). Over half of world silver production is estimated to have emanated from spectacular mines at remote Potosí in Upper Peru (modern day Bolivia) during this first global cycle of silver. Legal silver was transported via pack animal to the Pacific

${ }^{8}$ Extensive bibliography and analysis of precious metals in Spanish American can be found on Richard Garner's website (including references to his own works): http://www.insidemydesk.com/hdd.html Extensive bibliographic information is also maintained by John Munro at http://www.economics.utoronto.ca/munro5/2MEDMONEY2.pdf and at http://www.economics.utoronto.ca/munro5/2Pricerv4.pdf

${ }^{9}$ Artur Attman, American Bullion in the European World Trade 1600-1800 (Acta Regiae Societatis Scientiarum et Litterarum Gothoburgensis: Humanior) (Goteborg: Kungl. Vetenskapsoch Vitterhets Samhället, 1986), 78. 
coast, then shipped north to (present-day) Panama, transferred overland to Puerto Bello on the Atlantic-Caribbean side en route to Havana, where Peruvian silver joined Mexican silver exported via Vera Cruz to Havana. Heavily-armed Spanish fleets subsequently guided dozens of tons of silver per ship from Havana to Europe via Cadiz or Seville. In addition, threats of capital punishment failed to discourage smuggling of an estimated 50 tons of silver annually (about 2 million pesos worth) two thousand miles via Potosís socalled 'Back Door' to Atlantic ports Buenos Aires and Sacramento (along the Rio de la Plata, 'River of Silver'). ${ }^{10}$ African slaves constituted a major category of New World imports via the Atlantic; African slaves were essentially exchanged for clandestine (yet highly visible) American Back-Door silver exports during the (1540s-1640) Potosí-Japan silver cycle.

...settlers of Buenos Aires for most of the seventeenth century were relegated to a simple economy in which the port represented little more than the disembarkation point for Negroes and trade goods destined for the wealthier provinces of the interior and the embarkation point for the contraband silver that flowed out in exchange."

A portion of Peruvian silver that sailed northward along the Pacific Coast passed through Acapulco, outstanding East Pacific harbor, destined for arguably the best natural harbor in the West Pacific, Manila Bay. Manila was a linchpin entrepôt that teemed with Chinese merchants who had direct and indirect linkages to vast Chinese markets (European merchants in Asia similarly focused on silver and the Chinese marketplace). Although silver smuggled aboard Acapulco-Manila galleons obviously cannot be substantiated in official documents, we can infer shipment of approximately 50 tons of silver (i.e. 2 million pesos, most of which was smuggled) annually westward through Manila and onto China

${ }^{10}$ Zacarias Moutoukias, "Una forma de opisicion: el contrabando," in Governare Il Mondo: L'Imperio Spagnolo dal XV al XIX Secolo, ed. Massimo Ganci and Ruggiero Romano (Palermo: Societa Siciliana per la Storia Patria, 1991).

${ }^{11}$ Russell E. Chace, "The African Impact on Colonial Argentina” (PhD diss., University of California, 1969), 33-34. 
throughout the $17^{\text {th }}$ century; since two million pesos worth of Chinese silks are known to have entered Mexico via Manila annually during the $17^{\text {th }}$ century, an equivalent value of silver must have annually traversed westward toward China simultaneously. ${ }^{12}$

Once Spanish American silver reached Spain via the Atlantic, control of the white metal quickly passed to non-Spaniards. Portuguese and Dutch had established maritime footholds in Asia prior to Spaniards, thus (along with English, and other Europeans later on) having already secured crucial Asian entrepôts necessary to profitably channel silver to end-markets within China. Silver comprised the overwhelming percentage of the value of European shipments to Asia. Overall, perhaps three-quarters of Spanish American silver exports traversed the Atlantic Ocean, while the remaining one-quarter exited via Pacific Ocean exports. Whichever route - eastward via the Atlantic or westward via the Pacific - Chinese end-markets dominated global trade in silver via land and sea. American silver quickly passed through Spain. Amsterdam was a major distribution center in northern Europe; and an estimated 50 tons of silver traveled annually eastward through the Baltic Sea. ${ }^{13}$ Silver flowed through the Ottoman Empire, via the Silk

${ }^{12}$ According to Harry E. Cross, "Quantities of silver left the New World through the ports of Buenos Aires and Sacramento and through the Manila Galleons. At the peak of these activities, perhaps as much as 6 million pesos per year $(159,000 \mathrm{~kg})$, or half of the output of Peru, was diverted to these channels from the Seville trade." Cross, "South American Bullion Production and Export, 1550-1750," in Precious Metals in the Later Medieval and Early Modern Worlds, ed. J.F. Richards (Durham: Carolina Academic Press, 1983), 420. Following the lead of Han-Sheng Chuan, Dennis Flynn and Arturo Giráldez utilize evidence of Chinese silk exports to Mexico to infer flows of 2 million pesos (50 tons) of silver annually via Manila toward China. Chuan, "The Inflow of Silver into China from the Late Ming to the Mid-Ch'ing Period," Journal of the Institute of Chinese Studies of the Chinese University of Hong Kong 2 (1969): 61-75; Dennis O. Flynn and Arturo Giráldez , "Silk for Silver: Trade via Manila and Macao in the 17th Century," Philippine Studies 44 (First Quarter) (1996): 52-68. Ann even higher 2.5 million pesos flow has been estimated by George B. Souza. Souza, The Survival of Empire: Portuguese Trade and Society in China and the South China Sea 1630-1754 (Cambridge: Cambridge University Press, 2004), 84.

${ }^{13}$ Arthur Attman's estimates were restricted to European port shipments of specie - and not total land/sea shipments of specie and bullion - for two reasons. First, no documents recorded most overland shipments of specie or bullion: "No adequate sources are available in relation to the trade between East and West along the Continental land routes before the year 1700." 
Roads, Red Sea, Persian Gulf, and through virtually all overland/maritime trade routes that ultimately connected Europe and the Middle East to South and East Asia. Smuggling was rampant, including via numerous Mediterranean trade routes. Considering all European shipments together (except via the Portuguese), de Vries demonstrates that a steadily-growing stream of legallydocumented silver flowed to Asia via the Cape Route. ${ }^{14}$ As stated in Adam Smith's Wealth of Nations, and by countless other scholars over the centuries, China was the main attractor of American silver. Although rampant smuggling (partly to avoid tax payments) renders precise estimation of flows of American silver into East Asia impossible, such transfers were clearly on a scale that surpassed any experience in prior history.

\section{JAPANESE SILVER AND SINO-KOREAN-JAPANESE CONNECTIONS}

Prodigious Japanese silver mines were discovered in the 1520 at Iwami, western Honshu, followed in 1542 by discoveries at Ikuno (near Osaka). Chinese technology for extracting silver from ore was implemented in 1553 (by Korean miners via Tsushima): the haibuki process involved smelting lead and silver-containing ores, congealing them; ash was then blown onto the mixture in order to remove the lead. Silver production surged dramatically and Japan became the world's second-most significant silver exporter (behind Spanish America) from the middle of the sixteenth century into the seventeenth century. ${ }^{15}$ The vast majority of Japanese silver was exported

Attman, The Bullion Flow between Europe and the East 1000-1750 (Goteborg: Kungl. Vetenskaps- och Vitterhets-Samhallet, 1981), 10. Second, bullion was normally considered a special tax-exempt commodity; its flows were therefore unrecorded even at major ports. Attman, Dutch Enterprise in the World Bullion Trade 1550-1800 (Goteborg: Kungl. Vetenskaps- och VitterhetsSamhallet, 1983), 21-22. Thus, Attman did not claim to provide estimates of total West-to-East flows of silver or precious metals.

${ }^{14}$ Jan de Vries, "Connecting Europe and Asia: A Quantitative Analysis of the Cape-route Trade, 1647-1795," in Global Connections and Monetary History, 1470-1800, ed. D.O. Flynn, A. Giráldez, and R. von Glahn (Aldershot, U.K.: Ashgate Publishing Company, 2004), 32-69.

${ }^{15}$ First introduced into Korea from China in 1503, the ash-blowing technique for silver extraction was forwarded to Japan by a Korean official in 1539. Coupled with discovery of pro- 
to China (and to India, both as end-market and as re-exporter) due to surge in the price of silver within China. ${ }^{16}$ Chinese raw silk comprised the main item imported into Japan at the time.

Upon seizure of enormously profitable Japanese mines, the Shogun subdued hundreds of powerful feudal lords (daimyos), which eventually led to unification of Japan under the Tokugawa Shogunate (established in 1600).

The shogunate policy concerning precious metals was focused at first upon management and operation of mines. While taking power at the beginning of the $17^{\text {th }}$ century, the Tokugawa controlled all mines directly or indirectly, and seized the gold and silver produced there. ${ }^{17}$

The Tokugawa Bakufu, which took an active role in promoting mining and smelting technology, directly controlled all the silver and gold

digious silver deposits at Iwami and Ikuno, "[t]his new technique began to change Japan from a traditionally silver poor country to a major exporter." Kim, "Borders and Crossings," 208.

${ }^{16}$ For a clear overview of shifting Japanese metal exports - silver, gold, then copper during the $17^{\text {th }}$ century, Fujita documents shift of Dutch VOC exports from Japan via Taiwan into India and Persia (rather than into China): "Only 22 percent of silver was re-exported to other factories, mainly in India and Persia, between 1638 and 1649. Thus, we can say that the rest was paid to Chinese merchants and brought to China between 1638 and 1649. In contrast, 90 percent of the silver passing through Taiwan was transferred to India and Persia by the VOC between 1650 and 1661." (Kayoko Fujita, "In the Twilight of the Silver Century: A Re-Examination of Dutch Metal Trade in the Asian Maritime Trade Networks," Global History and Maritime Asia Working and Discussion Paper Series. Working Paper, vol. 1 (Osaka: Global History and Maritime Asia. 2005), 9. Fujita's emphasis upon "final destinations" deserves consideration: "Thus we need to be cautious about interpreting primary sources like invoices or manifests, since destinations cited in those forms at Hirado and Nagasaki factories were not always the final destinations of cargoes - especially when cargoes were shipped to transit ports such as Taijouan and Malacca." (Fujita, "In the Twilight of the Silver Century," 6) Fujita's "final destinations" correspond to our "end markets" terminology in this essay. Note that Fujita explicitly avoids any claim that Japanese silver exports to Bengal and Surat, for example, necessarily remained in those locations: "How Japanese silver re-exported from Taiwan circulated after entering the Indian subcontinent is beyond the scope of this paper. It may have been re-exported from India subsequently and ultimately absorbed in China. Further investigation is necessary." (Fujita, "In the Twilight of the Silver Century," 9) End-market destinations shifted over time, so overgeneralization concerning permanent trade patterns must be avoided.

${ }^{17}$ Kazui Tashiro, "Exports of Japan's Silver to China via Korea and Changes in the Tokugawa Monetary System during the $17^{\text {th }}$ and $18^{\text {th }}$ Centuries," in Precious Metals, Coinage and the Changes of Monetary Structures in Latin America, Europe and Asia (Late Middle Ages-Early Modern Times), ed. E. van Cauwenberghe (Leuven: Leuven University Press, 1989), 102. 
mined in Japan. After 1601, the Bakufu possessed a virtual monopoly over the gold and silver output. ${ }^{18}$

Chinese, Portuguese and Dutch exports of Japanese silver via Nagasaki have long occupied attention, and justifiably so, but Tsushima-and-Korea provided an alternative route through which silver reached China. Centered on Beijing, rhythms of the Ming tribute-trade calendar determined seasonal pulsations of silver siphoned into China through Korea. ${ }^{19}$ Massive smuggling of silver fueled private trade that accompanied (and often dominated) official tribute trade through Korea, as was true worldwide for smuggled silver.

Although initially displeased with the flow of Japanese silver via Tsushima and Korea to China, Choson Korea permitted the lord of Tsushima to send twenty silver-laden ships annually to Pusan in what amounted to a Korean leg of the tribute-trade system linked to China. There were no volume restrictions on private 'market trade' (kaesi) that accompanied official trade, so long as taxes were paid. Unsurprisingly, tax avoidance became the norm. Methods used to smuggle silver through Korea to China - via interpreters, horse drivers, luggage transportation, bogus 'loans' to Chinese, etc - are documented in Kim. ${ }^{20}$ Enormous demand for silver in Chinese markets, coupled with voluminous demand for Chinese silks, created irrepressible smuggling opportunities:

As the Vice Ambassador in the embassy in $1679 . .$. witnessed, many state offices preferred to receive Chinese raw silk, instead of silver, for their loan because Chinese raw silk was very popular among Tsushima merchants in Pusan. The market price of Chinese silk in Pusan was 2.7 times higher than that in China. ${ }^{21}$

${ }^{18}$ Kozo Yamamura and Tetsuo Kamika, "Silver Mines and Sung Coins: A Monetary History of Medieval and Modern Japan in International Perspective," in Precious Metals in the Later Medieval and Early Modern Worlds, ed. J.F. Richards (Durham: Carolina Academic Press, 1983), 347n.

${ }^{19}$ Tashiro, "Exports of Japan's Silver to China via Korea."

${ }^{20}$ Kim, "Borders and Crossings," ch. 4.

21 Ibid., 237. 
Korean transshipments of Chinese raw silks and Borderlands ginseng to Japan, of course, required equivalent exports of Japanese silver through Korea into China during this general period:

The rapid growth of ginseng trade, both official and illegal, therefore caused more than massive drainage of Korean ginseng to Japan. It also resulted in huge inflows of Japanese silver to Korea. In 1686, when Japanese silver import reached its highest point, 2,887 kan of silver came into Korea. This amount was six times greater than the amount exported from Nagasaki to China in the same year. The total amount of silver exported to Korea from 1684 to 1710 was 48,356 kan, or an annual average of 1,791 kan. ${ }^{22}$

In addition, Spanish American silver entered China via Manila and Ryukyu (Okinawa).

Ryukyu had long maintained tribute-trade relations with Ming China and Korea via provision of Southeast Asian products, but the situation changed and intensified when silver became a dominant global commodity:

[E]xchange of documents and presents between Korea and Ryukyu [now] took place at Huitongguan (the 'Residence Hall') in Beijing, where their respective envoys met. In other words, ...previous contact involved Japan, and the new contact brought China into the picture. ${ }^{23}$

After setting up a base in Manila [1571], Spain could not trade directly with Asia. But she recruited Chinese merchants to participate in the China-Manila trade, exchanging silver for raw silk. It would seem that Ryukyu merchants also participated in this trade, transporting into China not the usual products from Southeast Asia, but silver transiting Luzon. ${ }^{24}$

22 Ibid., 223.

${ }^{23}$ Takeshi Hamashita, China, East Asia and the Global Economy: Regional and Historical Perspectives, ed. Linda Grove and Mark Selden (London: Routledge, 2008), 65.

${ }^{24}$ Ibid., 80. 
Ryukyu secured the conditions to expand their trade from one which was hitherto restricted to procuring tributary goods from Southeast Asia to a much bigger network linked into the silver trade with Manila. Such conditions were created when large amounts of silver were supplied by Japan and the New World, making East Asia a silver currency zone focused on China. ${ }^{25}$

SILVER-BASED EMPIRES: HABSBURG SPAIN AND

TOKUGAWA JAPAN, AND QING OVERTHROW OF THE MING

How could Spain, a small country of six million inhabitants, become Europe's most feared military power in the latesixteenth/early-seventeenth centuries, having revolutionized neither domestic agricultural nor industrial sectors? The answer is straight-forward: profits based upon American silver. The Crown gained control over the richest silver mines in world history in Upper Peru and Mexico. Implementation of new technologies, such as the mercury-amalgam process, reduced production costs at mines that were already inherently fertile. Global demand for silver, thanks largely to developments within China, simultaneously bolstered the world price of silver. Low cost of production combined with soaring price is every businessperson's dream, of course, and high profit per unit of product was the result. The Spanish Empire was financed by extraordinarily high profits per unit of mined silver. Accumulating stocks of silver slowly depressed silver's price, however, until "excess profits" (which economists call 'economic profit') per unit of silver were finally eliminated around 1640. In short, it took a century for the world silver market to achieve equilibrium - that is, zero economic profit per unit of silver - by which time Spain had ineluctably become a second-rate power. Elimination of silver profits was inevitable, of course, but how did the Spanish Crown dispose of the mountain of super-profits generated over a century? Answer: Spain engaged in continuous warfare on a global scale. Expansion (followed by maintenance) of the Spanish 
Empire absorbed massive amounts of wealth. Given steadily eroding mine profits, maintenance - never mind enhancement - of infrastructure and development-inducing investment was impossible. Mine profits declined ineluctably in Japan as well, but the Tokugawa Shogunate confronted/created an environment strikingly different from that of Hapsburg Spain.

In an unrealistic attempt to conquer Ming China, 160,00o troops of Hideyoshi occupied Korea during1592-98 (prior to full unification of Japan itself). After this 1590 os invasion-of-Korea debacle, Japan morphed into an essentially market-oriented domestic society under Tokugawa rule, according to Hayami, ${ }^{26}$ albeit with mines, feudal families, and international trade firmly under control of the Shogun. In addition, centuries of Pax Tokugawa removed economic burdens associated with maintenance of vast military establishments.

Trade via Korea surged during the $17^{\text {th }}$ century (and into the $18^{\text {th }}$ century). The so-called “closure' of Japan in the 1630 - sakoku - did not prohibit trade. Rather, the Tokugawa Shogunate controlled international trade. Indeed, Japan became an important exporter of gold later in the $17^{\text {th }}$ century, ${ }^{27}$ and also emerged as the world's preeminent exporter of copper.

It was not until 1668...that copper emerged as the second most important commodity in the [VOC] Company's export trade with Japan, surpassed only by gold in terms of value. In the second half of the 1670 it became the single most important commodity. Although Japanese copper reached their peak in value around 1700 and then suffered a fall in value during the first decade of the eighteenth century, copper

${ }^{26}$ A. Hayami, "Great Transformations: Social and Economic Change in Sixteenth and Seventeenth-Century Japan," in Silkworms, Oil and Chips: Proceedings of the Economics and Economic History Section of the Fourth International Conference on Japanese Studies, ed. E. Pauer (Paris: Bonner Zeitschrift für Japanologie, 1986), 8.

27 The Sado Gold Mine (with over $400 \mathrm{~km}$ of underground tunnels) is estimated to have produced 80 metric tons of gold over 388 years (1601-1989), most of which occurred, again, under Tokugawa rule. 
still continued to occupy the largest share of export value from Japan. Consequently, it remained the most profitable commodity in this trade link. $^{28}$

Thousands of tons of Japanese copper entered China annually. Japanese copper exports to Europe were far smaller in scale, yet were at times significant:

During the peak years 1672-5, Dutch imports of Japanese copper equaled perhaps half of the calculated Swedish exports at that time. ${ }^{29}$

Nor should the role of copper as a ballast item be ignored:

The European trend in Japanese copper imports reached two peaks between 1650 and 1720 . The first peak occurred during the 1660 s and lasted until the 1670 , and the second was from the 1690 s to the 1710 ... The first large peak was caused by an increase in the demand for copper to be used for the casting of artillery pieces. Moreover, the fall in the price of sugar on the European market in the 1650 os and of saltpeter in the 1670 boosted Japanese copper imports into Europe, as both types of merchandise were goods necessary to maintain the balance of the ship's ballast so a substitute had to be found. During the first peak period, there were two hard-fought wars in Europe which affected the copper market... Indeed, the share of Japanese copper in the 1670 s was as high as one-third to one-half of Swedish copper. The second large peak is also attributable to a military demand for copper, especially in the first decade of the eighteenth century. ${ }^{30}$

Nonetheless, more than 90 percent of total reshipments of copper by the VOC were destined for South Asia, and the Dutch by no means monopolized the copper trade:

The VOC did not have a total monopoly. Copper was exported also from Nagasaki on Chinese junks and the Japanese exported copper on

${ }^{28}$ Ryuto Shimada, The Intra-Asian Trade in Japanese Copper by the Dutch East India Company during the Eighteenth Century (Leiden: Brill, 2006), 29-30.

${ }^{29}$ Kristof Glamann, Dutch-Asiatic Trade 1620-1740 (Hague: Martinus Nijhoff, 1981), 174.

${ }^{30}$ Shimada, The Intra-Asian Trade in Japanese Copper, 16. 
their own ships to Korea via the island of Tsushima. The final consumption markets for Japanese copper were worldwide.... The VOC carried the bulk of its Japanese copper to South Asia. Copper exported via Tsushima was delivered to Korea. Both China and Korea needed Japanese copper for minting copper currency. ${ }^{31}$

\section{ChineSE-KOrEAN-JAPANESE “Triangular TrADE”}

It was suggested earlier in this essay that silver from Central European mines may have found destinations in Chinese markets during the second half of the $15^{\text {th }}$ century, due to elevated Chinese silver prices in response to collapse of China's paper money system. If significant quantities of European silver did indeed enter China during the fifteenth century, then European silver must have also flowed into Japan via Korea: "It was the mid fifteenth century when silver began to be smuggled from Korea to Japan." ${ }^{22}$ It is unsurprising that few scholars emphasize fifteenth-century Korean exports of silver to Japan, given the dramatic subsequent reversal of silver's trade flow during the sixteenth century:

Such flows of silver from Korea to Japan were completely reversed by the mid-sixteenth century when Japan adopted the haifuki method and discovered two major silver mines [Iwami and Ikuno]... The more Japanese silver became available the more Korean traders were able to expand their business with China. The Choson court worried that, once the Ming court noticed this situation, Korea would be required to resume silver tribute. ${ }^{33}$

Massive quantities of (official and clandestine) Japanese silver flowed to - and mostly through - Korea into China during the sixteenth and seventeenth centuries. Since Chinese markets offered

\footnotetext{
${ }^{31}$ Ibid., 21-22.

${ }^{32}$ Kim, "Borders and Crossings," 214.

33 Ibid., 215.
} 
the highest silver prices in the world, the white metal was attracted to China irrespective of whether sources of silver were mines located in Japan, Spanish America, or elsewhere. Japanese silver exports exchanged directly for Chinese raw-silk imports through the first half of the $17^{\text {th }}$ century. ${ }^{34}$ The high price of silver in China - indicated by elevation of the base-height of the "China (End Market)" container in Figure 1 - provided intense motivation for shipments of silver to Chinese markets.

Figure 1. Japanese Silver via Tsushima and Korea into China, late $16^{\text {th }}$ and early $17^{\text {th }}$ Centuries

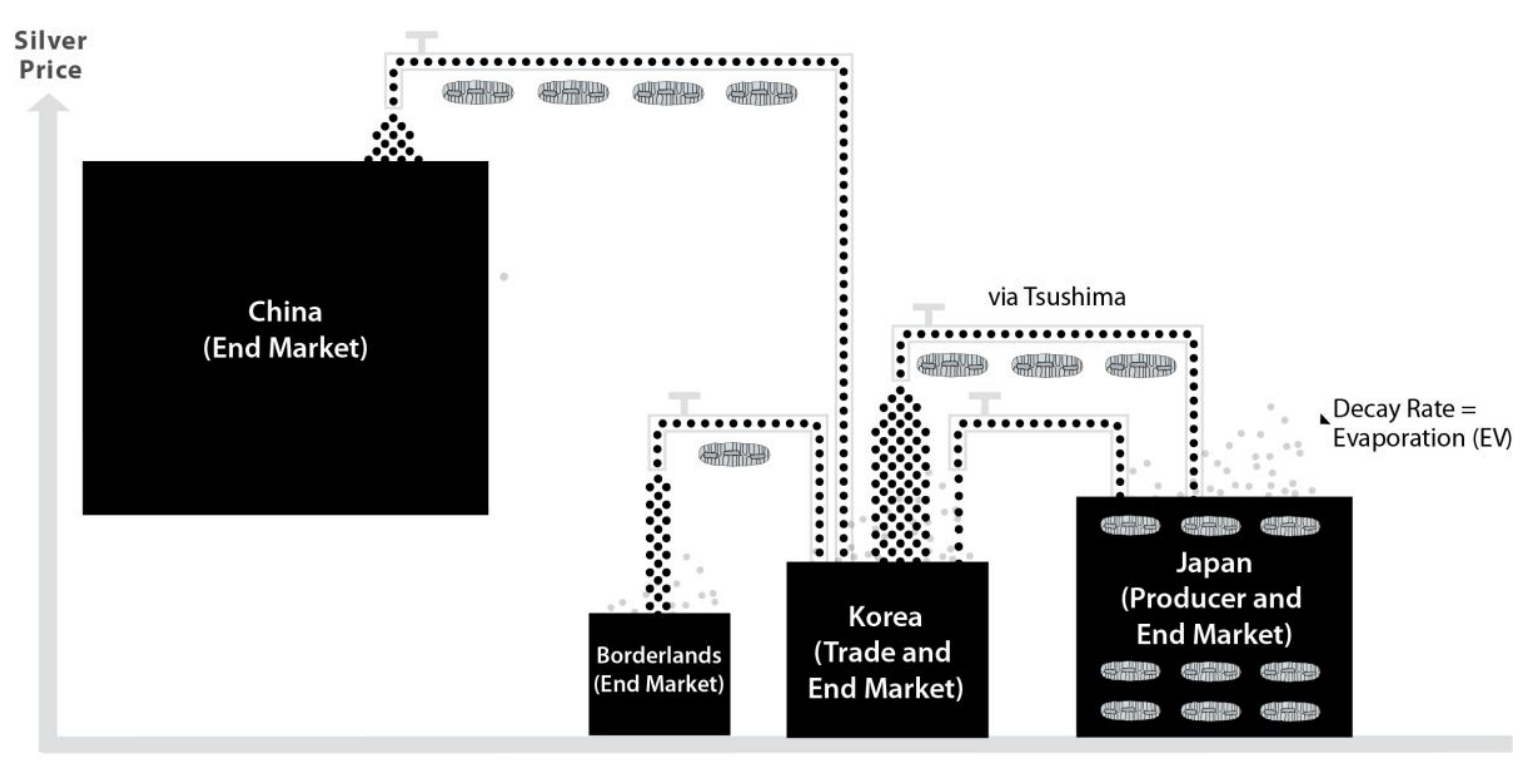

Container Volume = Inventory Supply (IS)

Container Volume capacity = Inventory Demand (ID)

Seonmin Kim's 2006 Duke University Ph.D. dissertation analyzes complex economic-political patterns across East Asia, and offers a coherent interpretation of Korea's involvement in the core

${ }^{34}$ This direct silk-for-silver exchange pattern also characterized trade across the Pacific Ocean. Spain's only direct access to Chinese markets, Acapulco-Manila galleons essentially transferred American silver westward (most-of-the-way) to Chinese markets in exchange for Chinese silks eastward bound into the Americas (some of which subsequently crossed the Atlantic Ocean into European markets). Dennis O. Flynn, A. Giráldez and J. Sobredo, "Introduction," European Entry into the Pacific: Spain and the Manila Galleons (Aldershot: Ashgate/Variorum, 2001), xxix-xxxi. 
Chinese-silk-for-Japanese-silver-exchange nexus. ${ }^{35}$ Korean access to officially-authorized Japanese silver was restricted to Japan House in Pusan. (Although smuggling was common, as elsewhere.) The So family, lord of Tsushima, was permitted to send twenty ships annually - laden with Japanese silver - to Korea beginning in 1609. Prodigious quantities of Chinese raw silk counter-flowed into Japan via Korea-Tsushima, as other scholars have emphasized for some time. ${ }^{36}$ Professor Kim's research reveals the unique and crucial role played by ginseng exports to Japan via Korea, however, a commodity destined to shape general East Asian history beginning in the second half of the sixteenth century. ${ }^{37}$

Figure 2 provides a general overview of major trade items connected to the silk-silver-ginseng exchange across East Asia. Major product groups were essentially swapped for each other over time. We next offer visual outlines of market forces that determined trade of specific items by region.

Korean ginseng had been the most valuable gift presented to Chinese emperors dating back to the $4^{\text {th }}$ century C.E. Borderlands between Korea and China contained unique concentrations of high-quality wild ginseng, which became the preeminent borderlands export-tribute item sent to both Ming China and Choson Korea by the second half of the sixteenth century. ${ }^{38}$ In exchange, the borderlands imported diverse finished products from China, while remaining fundamentally dependent upon Korean food imports that were "essential for [borderlands] survival." 39 In addition to

${ }^{35}$ See also Kim Seonmin, "Ginseng and Border Trespassing Between Qing China and Chosŏn Korea," Late Imperial China 28, no. 1 (June 2007): 33-61.

${ }^{36}$ See, for example, Tashiro Kazui, "Foreign Relations during the Edo Period: Sakoku Reexamined," Journal of Japanese Studies 8, no.2 (1982): 284-306.

${ }^{37}$ For elaboration on the theme of Korea's trade relations with Japan and China, see the January 2004 edition of Acta Koreana, including a "Guest Editor's Introduction" by James B. Lewis, "Guest Editor's Introduction," Acta Koreana 7, no 1, (2004): 1-7.

${ }^{38}$ In addition to ginseng, animal furs and pearls were the other major "Treasures of Manchuria" exports. Kim, "Borders and Crossings," 57.

${ }^{39}$ Ibid. 
Figure 2. Overview of East Asian trade items

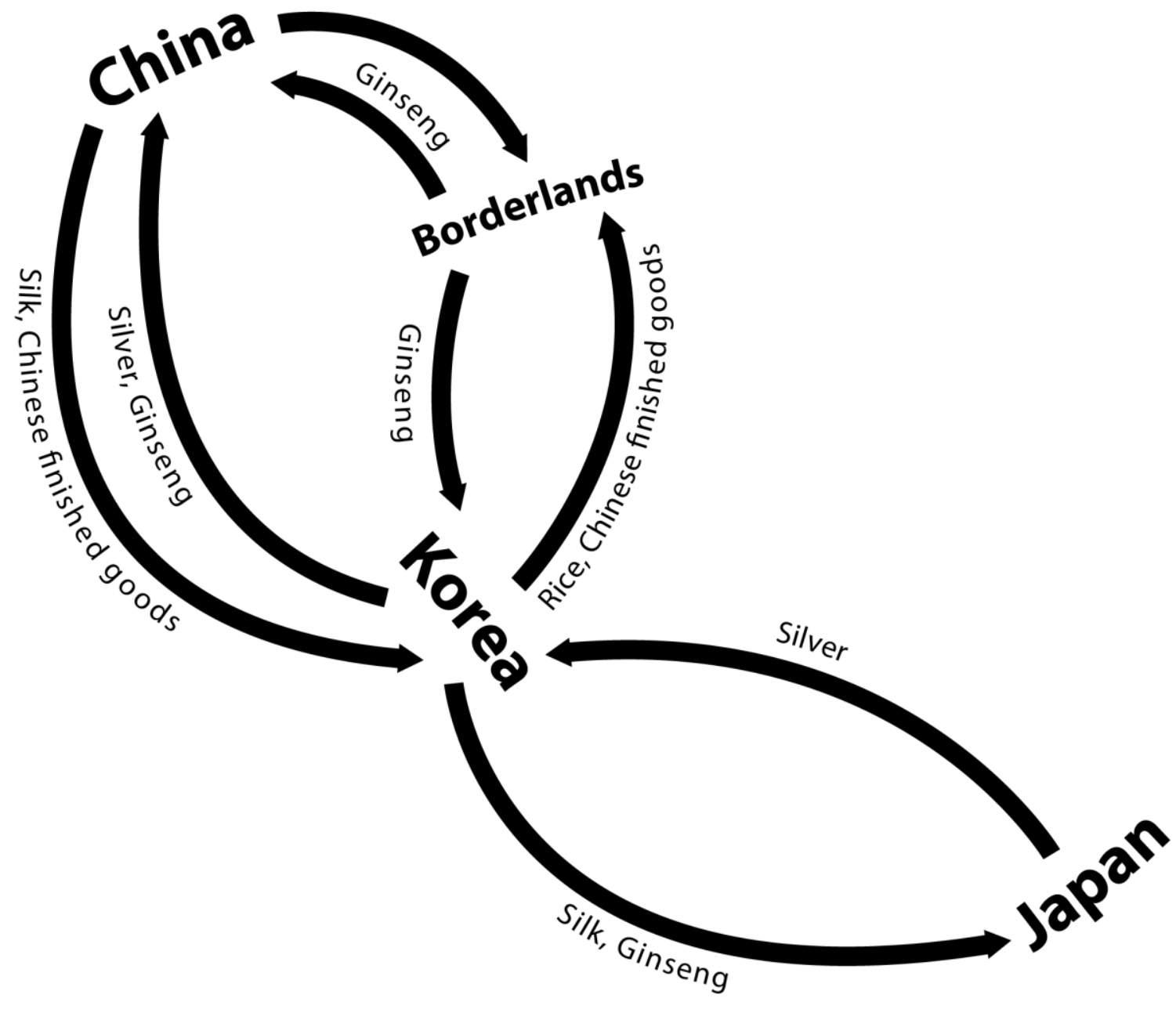

floods of Japanese silver entering China from the mid-sixteenth century, in other words, Professor Kim focuses upon the borderlands' ginseng counter-flow that entered Japan via Korea and Tsushima.

Since goods ultimately swapped for goods, Japanese silver exports traded for Japanese imports; Chinese silks and borderlands ginseng were the two most significant items that passed through Korea in exchanged for Japanese silver. Increase in volume of Japanese Inventory Demand for ginseng over time, congruent with expanding Japanese silver exports, is demonstrated visually via expansion of the "Japan (End Market)" ginseng container's volume in Figure 4 relative to the smaller "Japan (End Market)" ginseng container volume in Figure 3 (representing an earlier time period than Figure 4). 
Figure 3. Borderlands Ginseng Exports to China, Korea and Japan

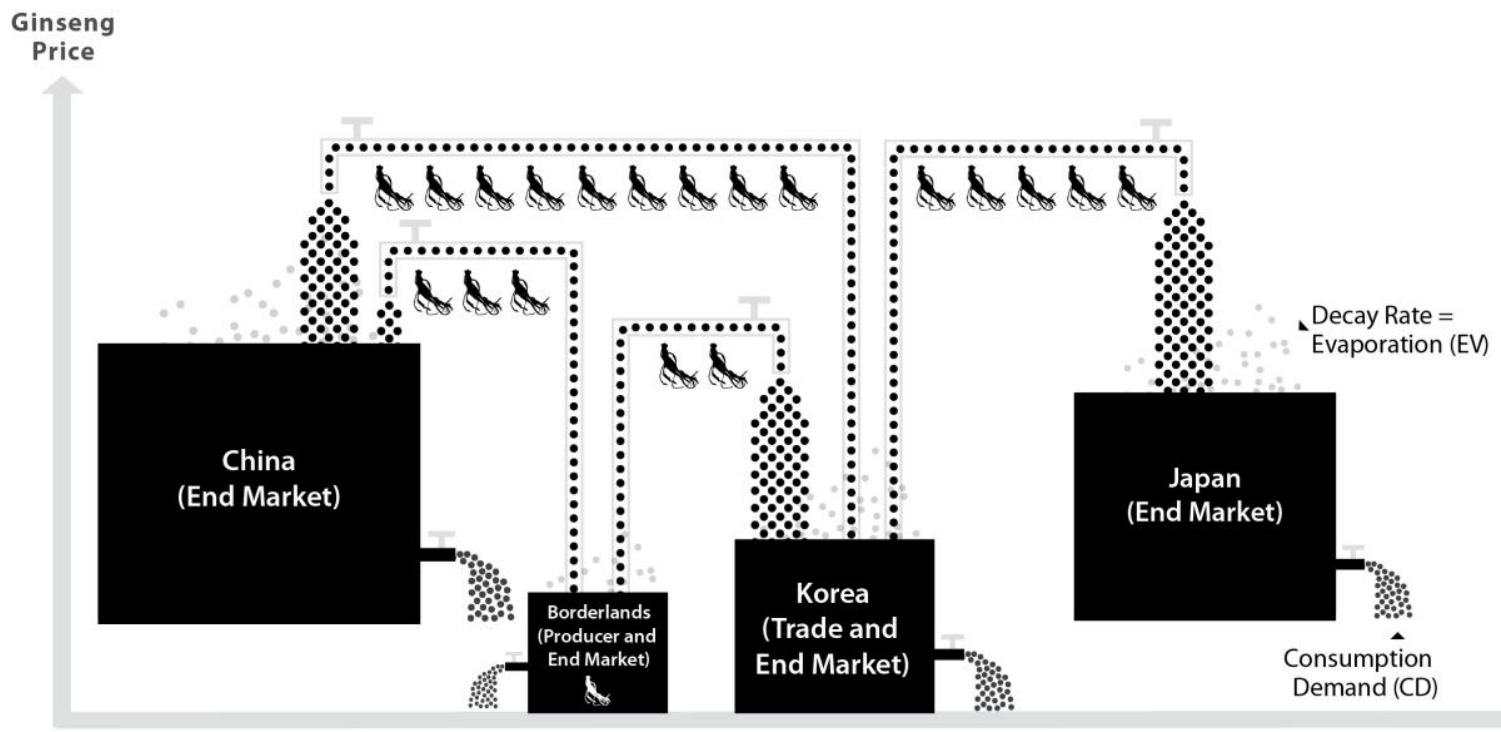

Container Volume $=$ Inventory Supply (IS)

Container Volume capacity = Inventory Demand (ID)

Figure 4. Growing Borderlands Ginseng Exports to Japan later on ${ }^{40}$

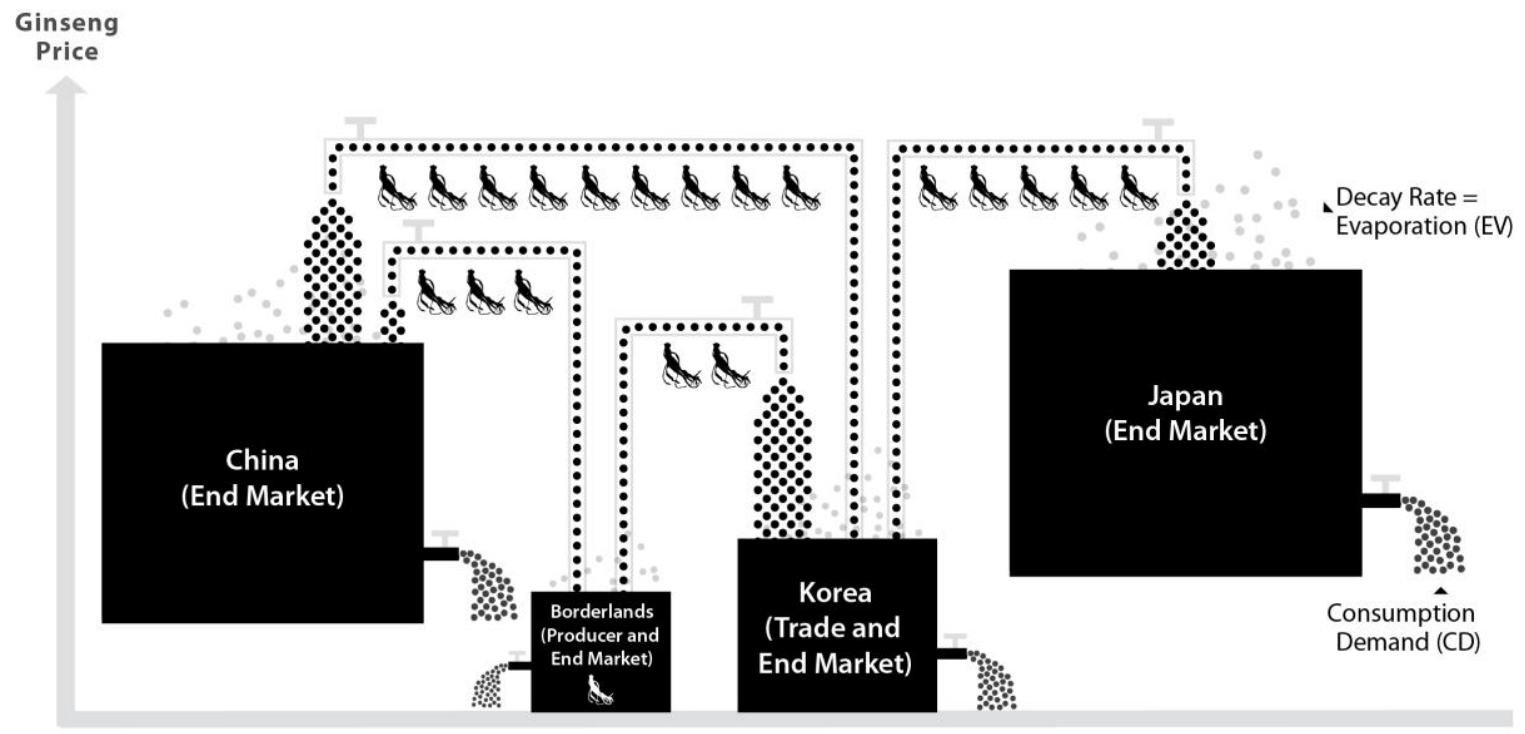

Container Volume $=$ Inventory Supply (IS)

Container Volume capacity $=$ Inventory Demand (ID)

${ }^{40}$ Note that Figure 4 is meant to show enlargement of Japan's container volume (i.e. Inventory Demand) over time. Enlargement of the Japanese container is not meant to imply anything about the size of Japanese Inventory Demand vis-à-vis simultaneous Chinese Inventory Demand for ginseng. I simply do not know relative sizes of these respective markets. 
Raw silks constituted China's most important export item throughout the sixteenth and seventeenth centuries, dominating eastbound cargoes aboard Manila-Acapulco galleons that crossed the Pacific Ocean, for example, destined for Mexico and beyond. ${ }^{41}$ This lucrative silk-for-silver-exchange pattern characterized Chinese-Japanese trade as well, enticing Asian and European merchants into the prodigious silk-for-silver trade. In this context, Korea played a central role in East Asia's silk-for-silver nexus, one facet of a massive set of interconnect market systems operating at a global level. ${ }^{42}$

As indicated in Figure 5, some (unknown to us) portion of Korean imports of Chinese raw silks must have been retained within Korea, since raw silks must have furnished inputs for Korea's domestic silk textile industry. Korean silk textile products (not shown here) may have been retained by end-market customers within Korea mostly, one would imagine, yet Korean silk textiles may have been exported (alongside Korean cotton textiles) to the borderlands as well. In any case, huge volumes of Chinese raw silks are known to have been re-exported from Korea to Japan.

${ }^{41}$ Chinese silks of various qualities proliferated throughout the Americas, but they also entered Europe via Havana. Thus, Spanish merchant complaints against relentless silver drains westward across the Pacific can also be viewed as pleas for protection against low-price Chinese silk imports into markets coveted by Europeans. Significant transportation expenses involved in crossing the Pacific Ocean, the breadth of Mexico, and the Atlantic Ocean notwithstanding, Chinese silks dominated. For an overview of massive exports of Chinese ceramics, another huge trade item, see Robert Findlay, "The Pilgrim Art: The Culture of Porcelain in World History," Journal of World History 9, no. 2 (1998): 141-87.

${ }^{42}$ Two explanations exist in the economic history literature for the origin of modern Globalization. Flynn and Giráldez argue that Globalization today dates from the $16^{\text {th }}$ century, while Kevin O'Rourke and Jeffrey Williamson maintain that modern Globalization dates from the 1820s. Charles Mann's environmental history best-seller 1493 (essentially an update of Alfred Crosby's pioneering work) supports the view that Globalization began during the $16^{\text {th }}$ century. Flynn and Giráldez, "Silver and Ottoman Monetary History in Global Perspective"; Flynn and Giráldez, "Path Dependence, Time Lags and the Birth of Globalisation: A Critique of O'Rourke and Williamson," European Review of Economic History 8 (2004): 81-108; Flynn and Giráldez, "Born Again: Globalization's Sixteenth-Century Origins," Pacific Economic Review 13, no. 3 (2008): 359-87; O'Rourke and Williamson, "Once More: When Did Globalization Begin?" European Review of Economic History 8 (2004): 109-17; Mann, 1493: Uncovering the New World Columbus Created (New York: Alfred A. Knopf, 2011). 
Figure 5. Chinese Raw Silks into Japan via Korea

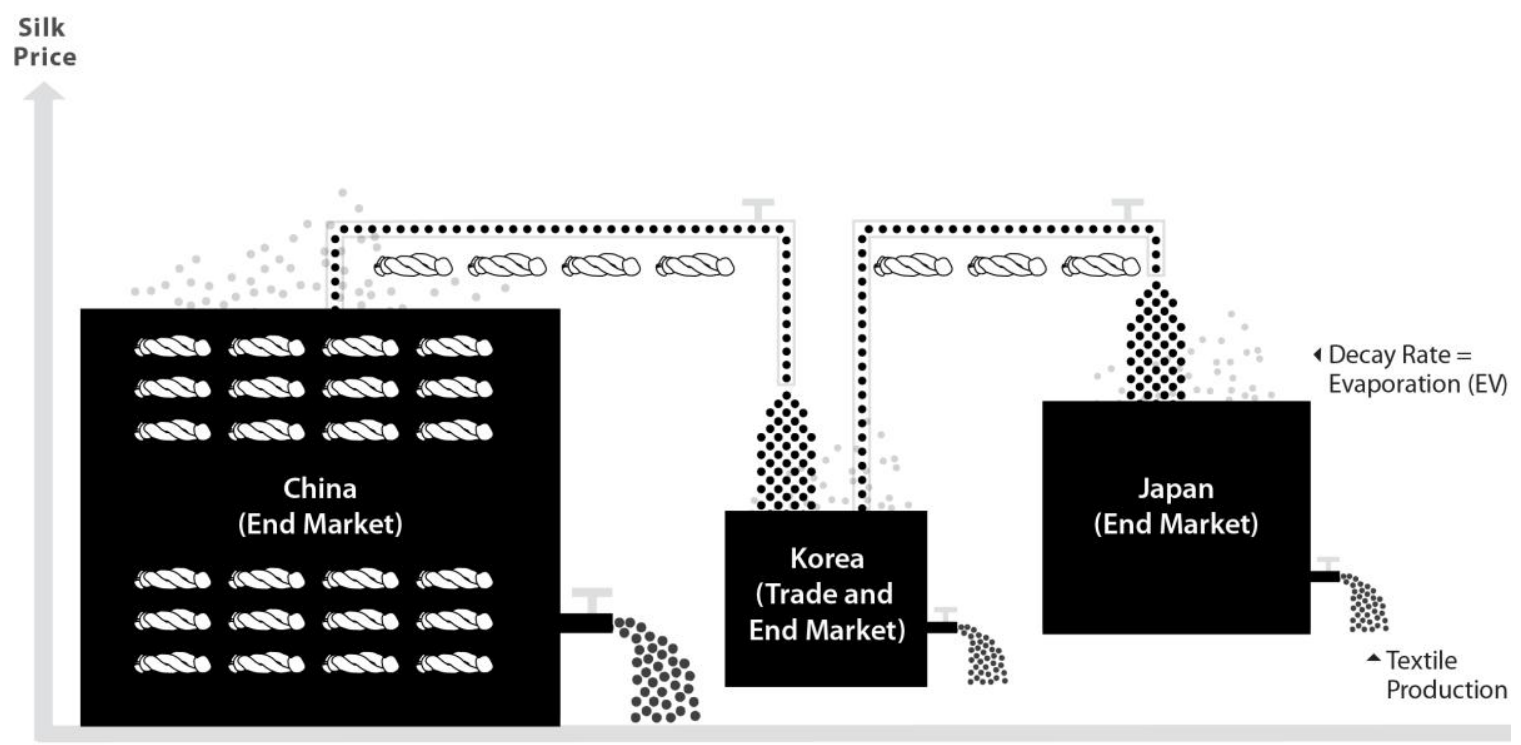

Container Volume $=$ Inventory Supply (IS)

Container Volume capacity = Inventory Demand (ID)

The three major borderlands export "Treasures of Manchuria" - ginseng, sable furs, and pearls - came under control of Jianzhou Jurchens:

His monopoly of trade with the Chinese provided Nurhaci with a solid economic ground on which to consolidate Jurchen tribes and later establish the Latter Jin... By the early seventeenth century, aside from booty, ginseng trade was the major source of income for Nurhaci's treasuries....Profits from ginseng trade were remarkable. As Imamura Tomo notes, it was not only his [Nurhaci's] military supremacy... but also his economic wealth from exclusive ginseng trade. ${ }^{43}$

Ginseng exports to Japan rivaled and perhaps surpassed ginseng exports to China itself over time (depicted via growth in Japan's container capacity in Figure 4 vis-à-vis Figure 3). Exports from the borderlands became sufficiently lucrative that they financed conquest of Choson Korea by Jianzhou Jurchens in the 1630s, as well as

${ }^{43}$ Kim, "Borders and Crossings," 58. 
subsequent overthrow of the Ming Dynasty in the 1640s. Originally vassals to both Choson Korea (in turn vassal to China) and Ming China, borderlands Manchus eventually achieved sovereignty over both. Absent economic wealth generated via ginseng exports, it is difficult to imagine how triumphant Manchus could have overthrown the Ming Dynasty and thereby establish the Qing Dynasty (1644-1911).

On the silver-side of the trade, the Shogun subdued over two hundred and fifty formidable daimyo lords after having gained complete control of rich Japanese mines, a requirement for unification of Japan under the Tokugawa Shogunate in 16oo. Japanese unification depended upon profits generated through over a half century of silver exports to Chinese markets. Indeed, silver profits financed Hideyoshi's dispatch of 160,00o Japanese soldiers to Korea in the 1590 en route to planned overthrow of the Ming Empire. This expensive invasion became a spectacular failure, but "Choson [Korea] first became aware of [Nurhaci, leader of the Jainzhou Jurchens]... in 1592 when he suggested sending his troops to help the Choson fight against Hideyoshi's invasion." 44 The Choson King could afford to ignore Nurhaci's offer of troops because Nurhaci had not yet developed into a threat to Korea (notwithstanding Nurhaci's challenge of Ming supremacy within the borderlands). Jurchen belligerence toward the Ming led to loss of access to Chinese markets via the tribute-trade system, of course, and this placed Jurchens and Koreans in awkward positions. The Ming ordered vassal Korea to send troops to defeat defiant Jianzhou Jurchens, yet Korea needed borderlands ginseng in order to obtain Japanese silver, in turn, required for sustenance of trade with China. At the same time, Jurchens survival depended upon importation of rice and other Korean foods (indicated in Figure 6). Korean and the borderlands economies had become mutually interdependent. 
Figure 6. Korean Rice/Food exports to the Borderlands

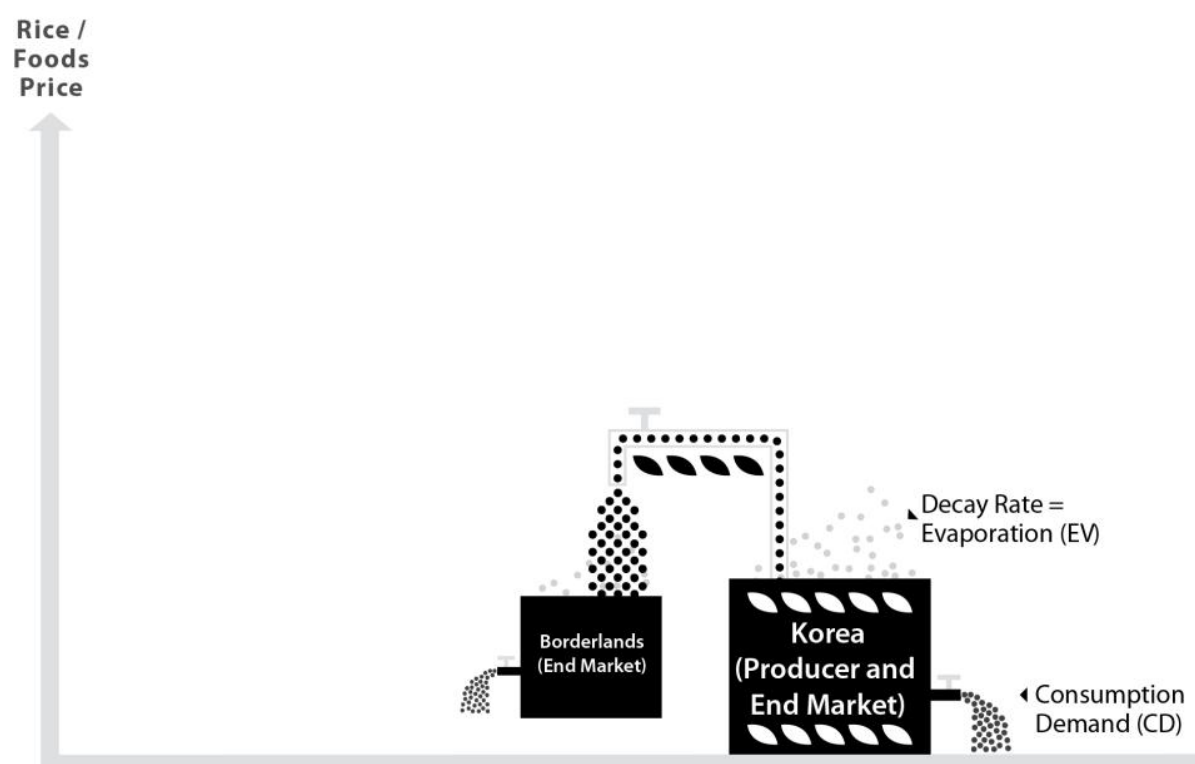

A vassal of China, however, Choson Korea had little choice but to send troops into the borderlands in half-hearted support of Ming military efforts. Ginseng-rich Latter Jin (another name for Jianzhou Jurchens) achieved sufficient resources over time, however, to afford a 30,0oo-troop invasion and defeat of Korea in $1627 .{ }^{45}$ Severe famine in Manchuria after the 1627 invasion, however, caused even greater urgency for borderlands acquisition of Korean foods. Successor to Nurhaci, Hung Taiji send 100,00o troops in brutal subordination of Korea in $1636 .{ }^{46}$ Hung then proceeded to fight through Inner Mongolia and to defeat northern Ming defenders in 1636. The (renamed) "Northern Jin" then proceeded to defeat Ming rulers, thereby founding the Qing Dynasty (1644-1911). The Qing continued to maintain full control of borderlands ginseng, of course, while also inheriting the traditional Ming role of importation of foreign silver in exchange for Chinese exports.

\footnotetext{
45 Ibid., 60.

${ }^{46}$ Ibid., 30.
} 


\section{GLOBAL SILVER IN THE EIGHTEENTH CENTURY}

Japanese silver mines had been mostly exhausted by the end of the seventeenth century. Japan became the world's largest exporter of copper by this time, however, much of which was again destined for end-markets in China. Significant quantities of Japanese copper entered European end-markets as well (via the Dutch). Japanese gold production surged too. Unlike Imperial Spain, in other words, the Shogun possessed considerable non-silver resources.

Thanks in large measure to dissemination of crops of American origin - especially the sweet potato, maize, peanut, and tobacco - China's landmass increased during the eighteenth century, while Chinese population more than doubled. Growth in Chinese population, in turn, augmented inventory demand for silver within China (strong movement back to copper-based monies within China notwithstanding). As a result of population growth, rising silver prices within China came to command a 50\% premium over silver's price in the rest of the world by 1700 . In conjunction with implementation of cost-reducing new mining technologies in Spanish America, this elevated silver price provoked an unprecedented silver mining boom during the "Mexican Cycle of Silver" that commenced around 1700 . As a consequence, $18^{\text {th }}$-century flows of silver into China surpassed silver imports during the $16^{\text {th }}$ and $17^{\text {th }}$ centuries combined. Elevation of the base of the container labeled "China (End Market)" in Figure 7 offers visual depiction of this price premium for silver within China vis-à-vis the rest of the world. Unsurprisingly, Spanish-American silver poured ever more relentlessly into Chinese markets that offered premium prices for silver.

Fifty years of unprecedented production and export of Spanish-American silver ultimately pushed silver's price within China down to the world silver price level by 1750 , as indicated by lowering of the "China (End Market)" container base to a level comparable to container-base heights elsewhere (Figure 8).. In economics jargon, "economic profits" diminished to zero, which means that actual profit rates fell to normal profit rates (typically experienced 
Figure 7. Silver into End-Market China during the Mexican Cycle of Silver around 1700

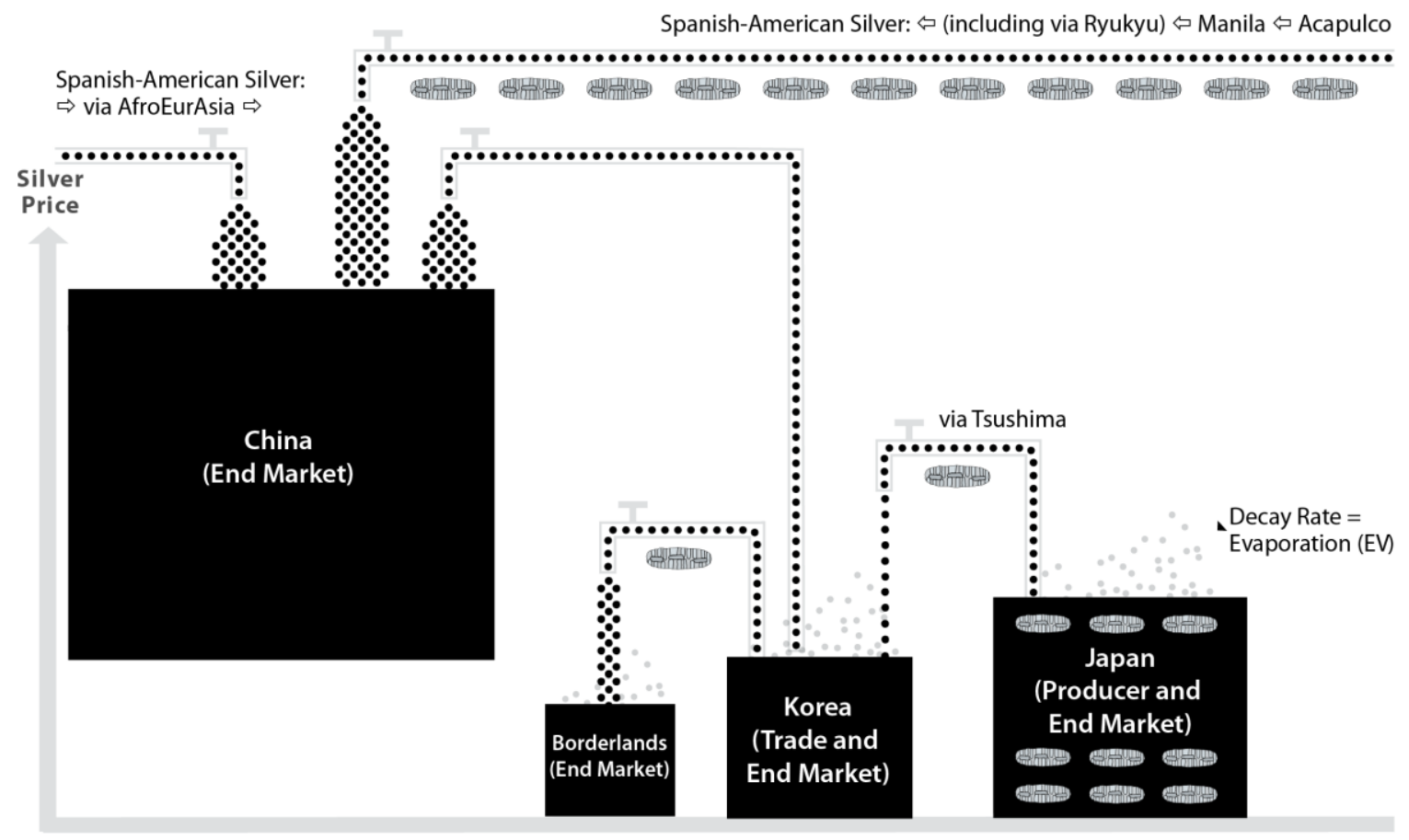

Container Volume $=$ Inventory Supply (IS)

Container Volume capacity = Inventory Demand (ID)

by industries generally). Mexican Cycle of Silver "super profits" had vanished by around 1750 , in other words, since fifty years of arbitrage trade resulted in accumulations of silver within China that eliminated arbitrage "super profits" that had existed during the half-century Mexican Cycle of Silver (1700-1750); elimination of "super profits" was a replay (on a larger scale) of the same outcome observed during the "Potosí-Japan Cycle of Silver" of the earlier 1540 -1640 silver boom period. ${ }^{47}$ "Normal profits" continued to entice importation of silver into China during the second half of the eighteenth century, that is, but profits associated with export of silver to China by this time had become pedestrian.

${ }^{47}$ Dennis O. Flynn and Arturo Giráldez, "Cycles of Silver: Global Economic Unity through the mid-18 ${ }^{\text {th }}$ Century," Journal of World History 13, no. 2 (2002): 391-427. 
Figure 8. Silver into End-Market China after 1750 during a non-arbitrage phase ${ }^{48}$

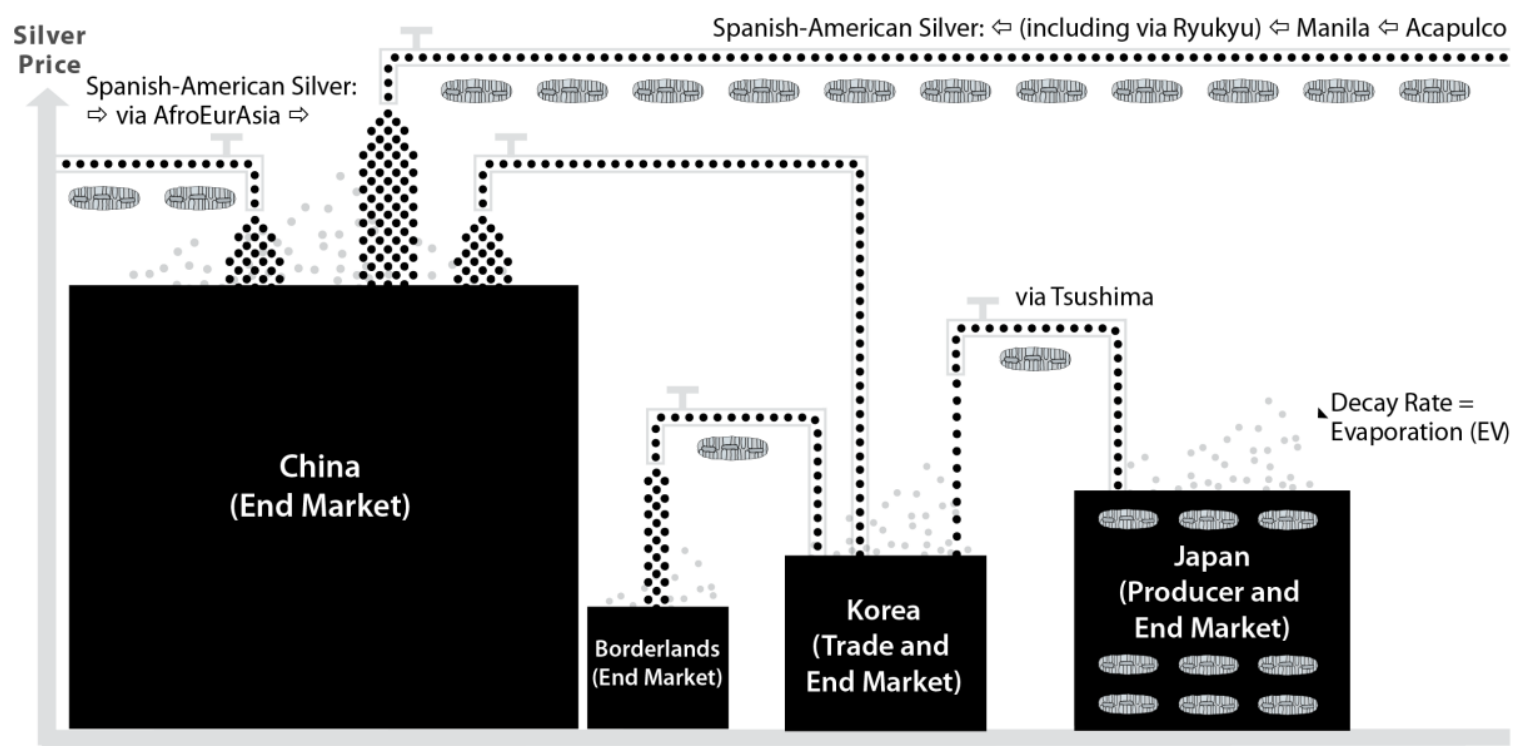

Container Volume $=$ Inventory Supply (IS)

Container Volume capacity = Inventory Demand (ID)

Readers may wonder how such vast quantities of silver could continue to enter China when silver-industry profits had dwindled to pedestrian levels: It is easy to imagine why merchants throughout the world concentrated on sending silver toward China when significant arbitrage profits were available - just buy silver where it is cheap and sell it where it is dear! But what market mechanisms explain China's absorption of silver during non-arbitrage phases, such as during the post-1750 period, when economic profits had fallen to zero? The Hydraulic Metaphor reveals market forces at work while silver continued to flow into unspectacular markets.

China continued to import millions of Mexican silver pesos annually during the second half of the eighteenth century, despite

${ }^{48}$ While Japanese silver was re-exported to China for the most part, some silver stocks remained within Korea itself: "In the sixteenth century, there was expansion in domestic production of silver that added to supplies of imported Japanese silver, but in the seventeenth century, there were two other factors that came to bear on the opportunity for a massive expansion in the circulation of silver. The first was while the Ming troops were stationed in Korea because of the 1592 Imjin Waeran, payment of their expenses introduced huge amounts of silver currency, and with its circulation, the supply expanded, and the taboo against the circulation of silver currency disappeared. The result was that in the seventeenth century, silver came to be widely used in the markets, even for the purchase of goods for daily use." Oh Doo Hwan, "The Silver Trade and Silver Currency in Chosŏn Korea," Acta Koreana 7, no 1 (2004): 91. 
elimination of all Chinese silver-price premia. For simplicity, assume that the stock of silver pesos held within China in, say, 1780 were equal to 500 million pesos (shown in Figure 9A). Assume further that one percent of the peso stock in China was either worn out or lost each year, a 5-million-pesos annual inventory loss represented by evaporation bubbles above "China (End Market)" in Figure 8. In the absence of imports of silver into China, in other words, China's inventory stock of pesos would fall to 495 million pesos (other things equal) after one year. Alternatively, existing Chinese silver stocks could be maintained from one year to the next if 5 million Mexican pesos were imported annually. And as had been the case for centuries, importation of foreign silver into China required that China export an equivalent value in goods in exchange for imported silver. For simplicity, assume that China's sole late-eighteenth-century export were tea, a consumable product (in contrast to silver, a non-consumable). Domestic Chinese tea consumption must have been substantial, yet vast quantities of tea were exported to Korea, Japan, other Asian markets, and increasingly to England (and elsewhere). Compared with silver, teas maintain freshness for a short time; inventory tea holdings are therefore relatively modest and teas are consumed quickly. Figure 9 deliberately depicts relatively small inventory holdings of tea within endmarkets in Korea, Japan and England; note that despite relatively modest tea inventories, tea consumption is nonetheless relatively robust. The essential point is this: Substantial annual imports of silver were required to replenish inventory stocks of nonconsumable silver within China because the inventory volume of silver held was vast. Although silver's decay rate may have been only one percent annually, one-one-hundredth of vast silver holdings implied importation of millions of silver pesos annually - just to maintain silver stocks. Inventory volumes of tea held outside of China were relatively small by comparison, on the other hand, yet Chinese tea exports were robust because consumption rates for Chinese teas worldwide were relatively high. Durable goods (such 
as metals) accumulate to a far greater extend than do non-durableconsumable goods (such as ginseng); proper conceptualization of trade history requires recognition of the crucial role played by accumulation of goods. Scholars need to pay attention to wealth accumulations, in other words, and avoid exclusive concentration on exchanges (income and expenditures) without recognition that the durability of a specific trade item matters.

Figure 9. Chinese Exports of Tea, a Consumable Good, during an Arbitrage Phase

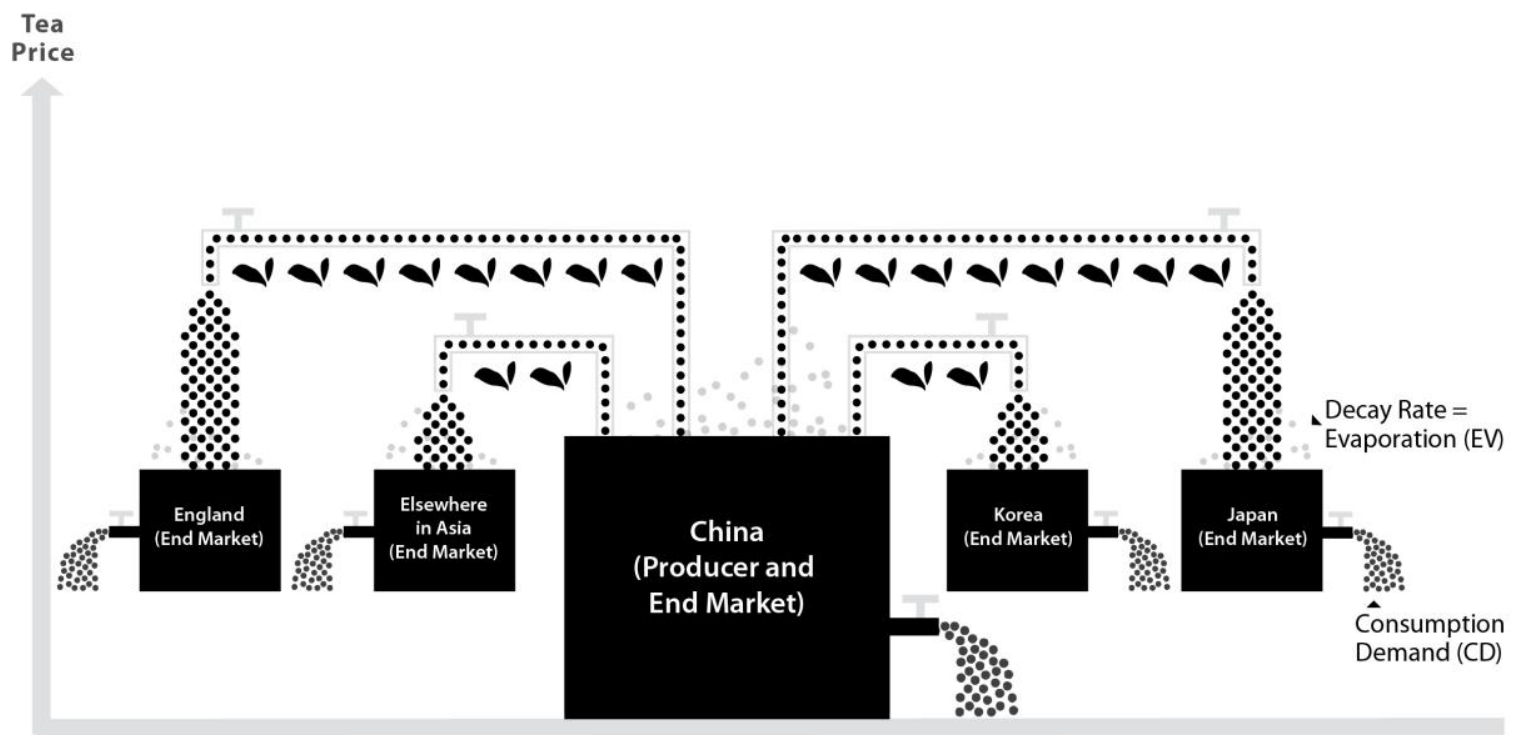

Container Volume $=$ Inventory Supply (IS)

Container Volume capacity = Inventory Demand (ID)

Note that profits need not be unusually high in order to justify replication of exports/imports depicted in Figures 8 and 9 over time. Key to understanding centuries of silver imports into China rests, once again, upon recognition that the volume of Chinese silver holdings was vast. Maintenance of a steady-state volume of silver inventories required importation of millions of silver pesos annually, which in turn required annual export of equivalent millions worth of Chinese silks, ceramics, teas, and other products. Although end-market inventory holdings of tea may have been relatively modest - compared with end-market inventory holdings of silver - tea quality is assumed to decline relatively quickly, leading 
customers to replenish relatively small tea inventories regularly. Chinese tea exports were robust because customers around the world drank prodigious quantities of the liquid continuously; Chinese imports of silver (a non-consumable) remained strong, on the other hand, because a small percentage loss (decay) of vast silver holdings implied importation of millions of silver pesos annually in order to replenish and maintain stocks.

Once the Chinese price of silver had again declined to silver's price in the rest of the world by 1750 (as happened previously around 1640), the lucrative Mexican Cycle of Silver had ended (in the sense that silver-industry profits shrunk to a normal level). Trade of silver was okay, but nothing that would over-excite merchants. Struggling merchants always search for vibrant trade opportunities, of course, and the opium market was next to present opportunity for huge economic profits (once Bengal came under British control from 1757). While it is the case that English East India Company exports of silver comprised two-thirds of total EIC exports to China by value during the late- $18^{\text {th }}$ century, silver's depressed price implied modest silver-trade profits (as shown in Figure 8 ). While Bengali opium accounted for only one-third of the value of EIC exports to China, on the other hand, the opium trade generated far greater economic profits (Figure 10) than did British silver exports to China, simply because opium prices in China were unusually high for some time (i.e. arbitrage opportunities in the opium business were excellent). In short, high monetary trade values do not necessarily imply robust profits; relatively small components of overall trade sometimes generate the bulk of profits. Profits generated through trade of silver were modest (Figure 8), for example, even though silver comprised two-thirds of overall British exports to China. English East India Company opium profits were strong (Figure 10), in contrast, even though opium exports to China were but half of EIC silver exports to China (in terms of value). 
Figure 10. English EIC Opium Exports from Bengal to China after 1757

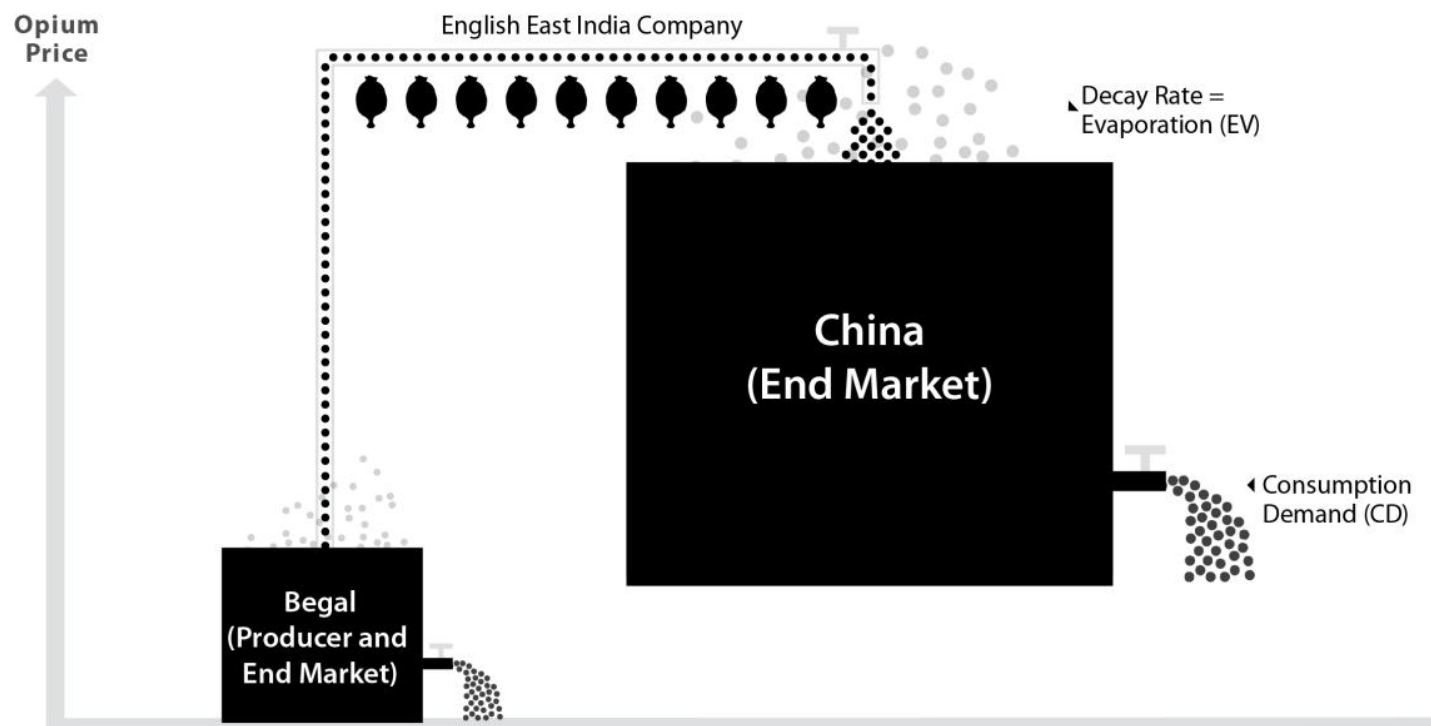

Container Volume $=$ Inventory Supply (IS)

Container Volume capacity = Inventory Demand (ID)

SUMMARY AND CONCLUSIONS

The trajectory of East Asian history veered dramatically during globalization's sixteenth-century birth. There is no denying that profits connected to global silver markets provided incentives to trade across all oceans, seas and major land routes. Nor is there doubt that inventory demand for silver within China, beginning in the first half of the $15^{\text {th }}$ century, spawned profit incentives for global trade once Spanish American silver surged prominently during the $16^{\text {th }}$ century. But there was a major Asian source of silver in nearby Japan, for awhile at least. Imagine if American silver had never existed, how would East Asian history have changed? Silver profits for the Shogun would have been far greater in the absence of American silver, since inventory stocks in China (and in the world) would have grown more slowly in the absence of American silver; slower-growing silver stocks would have implied slowerfalling silver prices worldwide. Slower decline in silver prices would imply higher profits for silver producers in Japan. One can only im- 
agine ramifications of a significantly richer, more powerful Shogun. ${ }^{49}$

But American silver did exist, and did stream into China and other world markets for centuries. American and Japanese silver mines were competitors in a competitive global marketplace, as discussed in general terms in this essay. ${ }^{50}$ Yet the role and significance of global silver flows cannot be fully appreciated without consideration of webs of products connected to, and exchanged for, silver. This essay focuses on a mere handful of key products traded across East Asian markets: Japanese silver headed for China; Chinese raw silk was destined for Japan, Korea, and borderlands; borderlands ginseng was exported to Korea, Japan and China; and Korean foods and other products were exported to the borderlands. Stocks and flows of all of these products were mutually interdependent. And volumes of one trade item vis-à-vis another trade item often did not correspond with the amount of profit associated with any particular trade item.

We do not pretend knowledge of the magnitude of profits generated by Manchus who gained control of areas of wild ginseng in the borderlands, but Kim argues convincingly that ginseng profits in essence financed consolidation of power by Jurchens, enabled invasion and conquest of Korea with 100,000 troops in the 1630s, and led ultimately to overthrow of the Ming Dynasty in the $1640 .^{51}$ Probably no one would claim that the ginseng market was among the world's largest markets, in other words, yet that niche market helped finance replacement of rulers of the largest economic entity on earth. Nor should the ginseng market be perceived in isolation;

${ }^{49}$ For comparison of Tokugawa Shogunate and Imperial Spain, see Dennis O. Flynn, "Comparing the Tokugawa Shogunate with Hapsburg Spain: Two Silver-Based Empires in a Global Setting," in The Political Economy of Merchant Empires, ed. James D. Tracy (Cambridge: Cambridge University Press, 1991), 332-59.

${ }^{50}$ Note that we are not utilizing the word "competitive" in the sense of "perfect competition" abstractions depicted in conventional economics textbooks, abstractions with no counterpart in history as far as we know.

${ }^{51}$ Kim, "Borders and Crossings." 
ginseng traded for Japanese silver, ${ }^{52}$ for Chinese silks and finished products, and for Korean food supplies that were indispensable for survival in the borderlands. It is the claim of this essay, presented in terms of the Hydraulic Metaphor, that interactions among these complex webs of exchange are best understood in terms of inventory demand and inventory supply mechanisms.

The Hydraulic Metaphor presents three notions of supply: Inventory Supply (the amount of the product that exists at a point in time), Production Supply (new units of product added to inventories during a time period), and Sales Supply (number of units sold off per time period, thus reducing seller inventory holdings). The Metaphor contains three parallel notions of demand: Inventory Demand (amount of product one desires to hold at a point in time), Purchase Demand (number of units purchased, and thus added to inventory, over a time period), and Consumptions Demand (units consumed per time period, in the sense that inventory is depleted). By way of contrast, conventional microeconomic theory contains just one concept of supply (production supply $=$ sales supply) and one concept of demand (consumption demand = purchase demand); in other words, inventories are excluded from conventional analysis. ${ }^{53}$

This is not the proper forum to discuss model technicalities. It is useful to keep in mind that our notion of "inventory supply," however, is equivalent to "population" in other disciplines. The

52 Just as Japan's silver boom came to an end, so too did borderlands ginseng succumb to inevitable market forces: "After a peak was reached in the seventeenth and early eighteenth centuries, ginseng exports to Japan declined after the 1750s. There were several reasons: ginseng imports into Japan from Qing China began from the 1710s; import substitution from Japan's domestic cultivation achieved success in the 1720s and the 1730s; imports from America began in the 1740s; and finally, wild Chosŏn ginseng became extinct from the middle of the eighteenth century." Kim Dongchul, "The Waegwan Open Market Trade and Tongnae Merchants in the Late Chosŏn Period," Acta Koreana 7, no 1 (2004), 18.

${ }^{53}$ The conventional microeconomic supply and demand apparatus is a special case of the Hydraulic Metaphor version of the Unified Theory of Prices. Conventional micro supply-demand is a theory of services - which by definition cannot be placed in inventories - and is not a theory of goods (which by definition can be placed in inventories) at all. Readers are invited to press the "services" button on the dynamic version of the Hydraulic Metaphor to see exactly why conventional analysis ignores the tangible world. www.unifiedtheoryofprices.org 
Hydraulic Metaphor focuses on mechanisms that determine the "population" of silver in China, the "population" of silks in Japan, the "population" of ginseng in China, Japan and elsewhere, and so on. Also, thinking in terms of "populations" facilitates simultaneous conceptualization of important environmental developments throughout history. For instance, introduction and spread of American plants - especially the sweet potato, maize, peanut, tobacco into China contributed to considerable increase in landmass of Qing China, and to more than doubling of Chinese human population during the $18^{\text {th }}$ century. Populations of food production in China exploded, in other words, which resulted in explosion and expansion of human population. In turn, growth in number of humans led to growth in inventory demand for innumerable products, including demand for silver, silks, ceramics, ginseng, foodstuffs, and so on. These interactive, recursive processes unfolded over generations and indeed over centuries. Societies today continue to evolve in the context of an interactive global setting in its fifth century. The purpose of this essay is to provide a simple outline of economic forces - via Hydraulic Metaphor - that are conceptualized in physical terms that can be related to concepts from disciplines beyond economics proper, including the physical sciences. Focus has been limited to certain $16^{\text {th }}-, 17^{\text {th }}$-, and $18^{\text {th }}$-century trade interactions across East Asia, while keeping in mind that all regional histories since the sixteenth century should be conceptualized in the context of overarching global narratives. 